\title{
A "maravilha" na poesia de Manuel Botelho de Oliveira
}

\author{
Adma Muhana (Dep. de Letras Clássicas e Vernáculas, USP, São Paulo, SP) \\ adma@usp.br
}

\begin{abstract}
Resumo: Trata-se de mostrar como a poesia de Manuel Botelho de Oliveira (Bahia, 1636-1711) visa construir a maraviIha principalmente por meio das consonâncias que surpreendem, numa poesia assentada em analogias com a "música", o "canto", o "verso", a "lírica", o "ritmo", a "doçura" - conceitos presentes em tratados retóricos, poéticos e filosóficos antigos, e que, aqui, se alçam a centro desta poética, distanciada da aristotélica. Evidencia-se como, diferentemente do conceito engenhoso, causa eficiente das agudezas poéticas, o poeta êmulo de Marino privilegia em sua Lira sacra e na Música do Parnaso a sonoridade que faz admirabile o dizer do poema, tangendo finezas ou as maneiras cantáveis do "plectro doce e fino".
\end{abstract}

Palavras-chave: poética; retórica; séculos XVII e XVIII; poesia brasileira; musicalidade.

\section{The wonderful in Manuel Botelho de Oliveira's poetry}

Abstract: This text explains how the poetry of Luzo-Brazilian Manuel Botelho de Oliveira (Bahia, 1636-1711) aims to build the wonderful especially through the consonances that provokes surprise, in a poetry grounded in analogies with the "music", the "chant", the "verse", the "lyrical", the "rhythm", the "sweetness" - concepts present in rhetorical, poetic and philosophical treatises of the Antiquity, and that here become center stage of this poetic, far removed from Aristotle. It highlights how, unlike the ingenious concept, the efficient cause of the acute poetry, the poet emulator of Marino favors sonority in the Lira Sacra and in the Música do Parnaso, his poem book. The musical elements turn admirabile what the poems says, playing finezas (niceties) or singable manners of the plectro doce e fino (plectrum sweet and gentle).

Keywords: poetics; rhetoric; XVII and XVIII centuries; brazilian poetry; music.

\section{Incipit}

0 poeta Manuel Botelho de Oliveira nasceu em 1636, na Bahia, e ai faleceu em 05 de janeiro de 1711, aos 75 anos de idade. Segundo Barbosa Machado, em sua Biblioteca Lusitana (publicada entre 1741 e 1758), Manuel Botelho estudou Jurisprudência Cesária na Universidade de Coimbra, e mais tarde exercitou em sua pátria, "com muito crédito", a Advocacia de Causas Forenses; exerceu também o cargo de vereador do Senado e capitão-mor. Quanto a suas obras, Barbosa Machado menciona somente a publicação, em 1705, do volume de poesias Musica do Parnaso, dividida em quatro coros de rimas. Todavia, menções de Manuel Botelho de Oliveira em suas poesias permitem tracejar algo mais de sua vida.

Pelos sonetos de n.107 e 108 da Lira Sacra, cujos títulos são À Capela da Transfiguração que fez o autor no seu engenho de Tararipe e Á Capela que fez o autor da invocação Nossa Senhora das Brotas no seu engenho de Jacumirim, sabe-se que Botelho de Oliveira possuiu dois engenhos no Recôncavo, pertencendo assim à florescente aristocracia açucareira da Bahia da segunda metade do século XVII. A localização desses engenhos permite-nos deduzir que o senhorio de sua familia deve ter se constituído nos primeiros anos de 1600, após a década próspera de 1580 para a lavoura do açúcar, quando as campanhas de Mem de Sá conquistaram aos índios a maior parte das terras do Recôncavo, cerne da região açucareira baiana. $\mathrm{Se}$, nos anos de 1580, havia no Recôncavo apenas 36 engenhos de açúcar, como informa o jesuíta Fernão Cardim nos seus Tratados da Terra e da Gente do Brasil, em 1629 são já 80 e, em 1676, contavam 130 - dois dos quais os do poeta Manuel Botelho de Oliveira. Isso fazia dele, portanto, um dos ricos senhores baianos, detentores de, no mínimo, dois engenhos, e que provinham de famílias solidamente implantadas na atividade antes da crise de 1680 - quando houve uma drástica baixa no preço do açúcar.

Não é improvável que um dos engenhos existentes na ilha de Maré também pertencesse à família de Manuel BoteIho de Oliveira. É sabido que em todas as invasões holandesas à Bahia houve incêndio e destruição de engenhos, e a uma delas, explicitamente, se refere Manuel Botelho, nos conhecidos versos da silva $\dot{A}$ ilha de Maré:

Nesta ilha está muita ledo e mui vistoso 
Um engenho famoso

Que quando quis o fado antigamente

Era rei dos engenhos preminente

E quando Holanda pérfida e nociva

0 queimou, renasceu qual Fênix viva.

A capela de Nossa Senhora das Neves na ilha de Maré também é destacada por Manuel Botelho de Oliveira logo a seguir à menção ao engenho, no mesmo poema: Aqui se fabricaram três capelas / Ditosamente belas / Uma se esmera em fortaleza tanta, / Que de abóbada forte se levanta; / Da Senhora das Neves se apelida - numa provável alusão a combates com os holandeses, nos quais mais de uma vez construções da ilha de Maré desempenharam importante papel defensivo para as terras interiores do Recôncavo.

Quanto aos cargos no Senado da Câmara que Manuel Botelho de Oliveira desempenhou, em nada destoam dessa sua atividade primeira de rico senhor de engenho; pelo contrário, tanto quanto a profissão das armas, a atividade política era dever e privilégio de senhores de engenho: entre as décadas de 1680 e 1730, metade dos vereadores da Câmara de Salvador era constituída por senhores de engenho (SCHWARTZ, 1999, p.233). Manuel Botelho de Oliveira cumpriu o percurso habitual da maior parte deles: após um bacharelado em Leis na Universidade de Coimbra, foi designado para cargos de comando em campanhas militares, até receber indicação para desempenhar um cargo político-administrativo. Nesta condição, participou dos principais acontecimentos econômico-sociais da colônia no século XVII, nos quais a Câmara defende sempre os interesses dos fazendeiros de cana-de-açúcar e senhores de engenho, os quais, por sua vez, instantemente exigem da metrópole reconhecimento por se considerarem responsáveis pela riqueza não só da Bahia e do Brasil, mas do império português como um todo.

Em meados do século XVII, evaporados os fumos do Oriente, solapados pela incapacidade da coroa portuguesa em manter as feitorias espalhadas por regiões tão vastas como Brasil, Guiné, Costa da Mina, Angola, Moçambique, Sofala, Diu, Damão, Goa, Macau e outras, às quais holandeses e ingleses, já conhecidos os caminhos maritimos, chegavam e pirateavam com facilidade, Portugal, efetivamente, deposita suas esperanças de riqueza no Brasil, que se situa a apenas 50 dias de distância, e onde uma agricultura de bens de raiz movimenta todo 0 Atlântico, por meio de intensas trocas de farinha de mandioca, tabaco e escravos como carros-chefes.

É comum, em demasia, chegarem à Bahia naus da Índia com apenas parte da carga ocupada (ou, quando atacada por piratas, com nada), preenchendo o restante com produtos do Brasil, daí levados para o reino, como relata o padre Antônio Vieira em carta a Diogo Marchão Temudo, de 1691:

Da Índia tivemos nau com cinco meses de viagem e mais de cem homens mortos, livrando-a Deus tão mal guarnecida de encontrar os corsários, que não cessam de infestar esta costa, e fizeram naufragar nela miseravelmente e sem socorro um navio, que em distância de duas léguas tinha saído deste porto carregado para as ilhas. As novas que trouxe a dita nau foram de ser morto o governador, e também o que The sucedeu [...] e que não há cem portugueses em Goa. Dizem aqui que vem carregada de pedraria, porque não trouxe mais que pedras, em lugar das quais levará setecentas caixas de açúcar, e irá descarregar na alfândega à vista da pobre Casa de Índia. (VIEIRA,1997, t.iii, p.630-631)

Este é o drama do império no Seiscentos, que levou ao transplante oficial de drogas orientais para o Brasil, à criação da Companhia das Índias Ocidentais e à construção de um estaleiro na Bahia para viabilizar a manutenção do comércio da África e do Oriente. A este estaleiro arribavam naus avariadas, espedaçadas, empestadas, que, oriundas de Goa, apenas em casos de extrema necessidade escalavam no porto insalubre de Moçambique e, passado o Cabo, dificilmente chegavam a Lisboa sem atracarem em Salvador - seja para se abastecerem de água e víveres, seja para reporem baixas da tripulação, seja, até, para contrabandearem, ou completarem a carga com açúcar, de modo a tornarem lucrativa a custosa viagem. Em princípios do século XVII, não é raro que naus do reino em direção à Índia também estanciem em Salvador para receber tabaco, o qual é consumido na distante Macau. Em certas rotas, as naus em torna-viagem da Índia ainda armazenam, do porto de Salvador, mandioca e tabaco, que são comercializados em Angola e na Costa da Mina.

0 fato é que desde meados do Seiscentos, é o Brasil o grande produtor de bens do império, proporcionados pela economia açucareira: "quem diz Brasil, diz açúcar, pois o açúcar é a cabeça deste corpo místico que é o Brasil" (Carta dos senhores e lavradores de cana de 20 de junho de 1662). Inversamente, perdido o Brasil, perde-se Angola, o Oriente já quase todo perdido. A inserção plena de Manuel Botelho de Oliveira na vida econômica, política e administrativa da Cidade do Salvador e do Recôncavo baiano - capital da América portuguesa e encruzilhada entre 0 Oriente, África e Europa - esclarece o caráter panegírico de mais de uma dezena de composições de Música do Parnasso, pertencentes aos "coros" dos vários assuntos não-amorosos, em todas as quatro línguas do livro, que evidenciam a inserção dos recôncavos baianos no mundo ocidental, mesmo que num fundo ensolarado do Ocidente.

\section{A lírica música}

A maior parte dos poemas de Música do Parnasso, porém, compõe aquele que se pode chamar "cancioneiro de Anarda" e, do mesmo modo que os poemas religiosos da Lira Sacra, inscrevem-se numa manifesta estrutura lírica. A lírica se destina a cantar seja a beleza, o bem amoroso, a amada, seja os homens virtuosos cujos feitos são dignos de se guardar na memória. A razão é horaciana: é da Musa lírica celebrar os deuses e os vitoriosos, bem como as preocupações e despreocupações juvenis (Musa dedit fidibus divos puerosque deorum et pugilem uictorem et equum certamine primum et iuvenum curas et libera uina referre, HORÁCI0, 1993, vv.83-83). Essa é a razão por que, mesmo nos poemas que tratam de personagens que realizam feitos políticos ou guerreiros, o tom se mantém panegírico, sem grandiloquências bélicas. E mesmo esses poemas são exceções, numa obra 
como Música do Parnasso, em que a maior parte trata de eventos de pequena dimensão, frente a um éthos épico, ou trágico. A "banalidade" do assunto é programática, numa poesia que, epidítica, tem na exibição da agudeza do poeta uma das principais fontes do deleite lírico, ocasião para maravilhar o leitor/ouvinte. Percorre-se os títulos de qualquer um dos "coros" e aí se vê um extenso rol de circunstâncias tipificadas, cuja matéria poética é amplificada pelo engenho do poeta com adornos líricos, isto é, com figuras que mostram com suavidade e brandura as ocasiões: Iras de Anarda castigadas, Rigores de Anarda na ocasião de um temporal, Não podendo ver a Anarda pelo estorvo de uma planta, Anarda temerosa de um raio, Cabelo preso de Anarda etc.

A constituição lírica que enforma essas obras, Música do Parnasso e Lira Sacra, é enfatizada nos prólogos de ambas as obras, que se enraízam na caracterização do gênero, mostrando a vinculação, enaltecedora, do gênero lírico com a arte da música. Este principal aspecto da poesia de Manuel Botelho de Oliveira deve ser destacado, tendo em mente que a poesia lírica e a música tomam-se, uma à outra, como referências imitativas desde os antigos retores - Plutarco, Dionísio de Halicarnasso e Quintiliano, por exemplo - e que desde fins do século XVI, no que diz respeito às preceptivas poéticas, os autores estabelecem a filiação do gênero poético em questão, o lírico, com o respectivo instrumento musical: "la lírica tomó nombre de instrume[n] to músico" (PINCINIAN0,1596, p.425). Não qualquer música, claro, mas aquela que se converte em hinos aos deuses, tocada pela lira do deus Apolo, que não pela flauta rude e pastoril do homem Mársias, ou do embriagado deus lascivo Dioniso.

Já no que diz respeito a escritos sobre música, desde por volta de 1570, ela é percebida como tendo por objeto de imitação o "instrumento da voz humana". Com isso pretende-se que a voz, além de dar forma aos conceitos que se representam ao intelecto, é capaz de enformar o canto, mímese da expiração natural dos afetos e modo do dizer, assim, superior, por capaz de carregar em sua estrutura sonora os variados afetos da alma (CHASIN, 2004, p.33-34). Daí que seja o canto, isto é, a palavra musicada, compreendido como um modo de dizer aperfeiçoado, e formas poéticas como a cantata, o madrigal, a canção, por sua vez, aquelas reconhecidas como as mais adequadas para, em associação com a música, demonstrar e provocar os afetos - movere - ofício maior de qualquer discurso ou poema. Principalmente, pensa-se que essa palavra musicada corresponde à palavra cantada da mais elevada poesia grega, a da antiga tragédia. Maravilhar, com peripécias e reviravoltas de ação, mas também de linguagem, é arte dos melhores poetas.

Quanto às várias relações lembradas pelos preceptistas entre a palavra poética e a palavra cantada, como são do domínio da arte da música, não cabem ser desenvolvidas aqui. Vale lembrar apenas que, na Poética (especialmente nos capítulos VI e XIX), Aristóteles é claro em afirmar que a pronunciação por meio de palavras faladas (da arte do ator), a música ou melopeia e a cenografia (da arte da representação), sendo alheias à essência da imitação poética (constituída por ação, caracteres, elocução e pensamentos), são consequentemente alheias à poesia. Apesar do menosprezo a ele devotado pela matriz aristotélica (inclusive na Retórica), o desempenho rítmico e tonal da oralidade não foi desconhecido das preceptivas retóricas gregas e latinas. Entre os manuais gregos, o Peri synthéseos onomaton (De compositione verborum) de Dionísio de Halicarnaso, partindo do pressuposto de que há colocações de palavras mais prazerosas e belas do que outras, segundo o ritmo, a melodia, a variação e (compreendendo as três) a adequação, procura estabelecer quais reuniões de palavras são mais doces, eufônicas, graciosas e sedutoras ao ouvido - "nisto semelhante à vista que, quando contempla imagens, pinturas, esculturas etc., se logra captar a alegria e beleza que há nelas, se sente satisfeita e não deseja mais" (Halicarnasso, 1985, Secção 10, 8-11).

À semelhança daqueles paralelos fartamente elencados entre a pintura e a poesia nas preceptivas acerca da pintura, ocorrem portanto, nos textos do Quinhentos e do Seiscentos vários paragones entre a poesia e a música, fornecendo-lhe um lugar entre as artes miméticas e seus cultores. Tal se evidencia, por exemplo, na carta de Girolamo Mei a Vincenzo Galilei, de 1572:

creio, portanto, que o fim proposto pelos antigos era imitar a própria natureza do instrumento do qual se valiam [a voz humana] [...] mas ao exprimirem inteiramente e com eficácia tudo aquilo que o falar desejava fazer entender com o seu significado por meio e ajuda da agudeza e gravidade da voz [...] faziam-na acompanhar com a temperatura regulada do presto e adágio, cada uma de per si pela própria natureza é acomodada a um determinado afeto. [...] E que este devesse ser o verdadeiro fim, e próprio alvo dos antigos músicos, mostra-o certamente o que se disse, e o confirma indubitavelmente ver que a faculdade dos músicos no princípio era ligadissima à poesia, sendo que os primeiros e melhores foram a um só tempo músicos e poetas. [apud CHASIN, 2004, p.33-34 (trad.) e p.150-151 (orig. ital.).

Em princípios do Seiscentos, é possível encontrar coletâneas de madrigais e demais formas líricas musicadas por compositores como, entre outros, Caccini e Monteverdi, o qual escolheu poemas de Petrarca, Tasso, Marino, Guarini, Rinuccini etc., para realizar a arte maior de efetuar na música a escala das paixões humanas, convencidos de que a música e a poesia eram, na Antiguidade, téchnai que tinham princípios e fins equivalentes, quais sejam, imitar e mover afetos.

Tantas razões, consolidadas já em princípios do Setecentos, fazem Botelho de Oliveira intitular suas obras "Música" do Parnasso e "Lira" sacra, em cujos títulos ecoa a lembrança do cavalier Giambattista Marino, um dos poetas modernos elogiados por ele na dedicatória do Música do Parnasso; aí, além dos antigos Homero, Ovídio e Virgílio, Oliveira destaca entre os modernos o "grande Tasso", o "delicioso Marino", o "culto Góngora", o "vastíssimo Lope", o "insigne Camões", Jorge de Montemor e Gabriel Pereira de Castro. Marino, do mes- 
mo modo, denominara de Rime sua primeira obra lírica (1602), à qual acrescentou em 1608 uma terceira parte, dando ao novo conjunto o título de La Lira. É sobretudo na "suavidade do metro", ambicionada pelo poeta da Ilha de Maré, que se reconhece o modelo da poesia de Marino, emulada no léxico, nas rimas, nos vocativos, nos ritmos, nas imagens e nas tópicas marinianas, e isso não só nos poemas italianos de Botelho de Oliveira, como em poemas seus portugueses e castelhanos. É certo que essa imitação tem diversos intermediários - em particular, Lope de Vega e Gôngora -, o que minimiza a importância da identificação das fontes. Porém, nas linhas mestras da poética de Botelho de Oliveira, permanece a concepção, fortemente mariniana, de que a poesia lírica é arte "irmã" da Música, como se canta no Adone: "Musica e Poesia son due sorelle / ristoratrici del'afflitte genti, / de' rei pensier le torbide procelle / con liete rime a serenar possenti" (canto 7, estrofes 1-2).

Soa assim mariniana a definição (incomum nas letras seiscentistas lusitanas), proposta por Botelho de Oliveira no prólogo a Música do Parnasso: "Poesia não é mais que um canto poético, ligando-se as vozes com certas medidas para consonância do metro". Há de se lembrar que o estudo dos versos, dos pés, das sílabas, assonantes e consonantes, fora relegado pelos preceptistas desde 0 século $\mathrm{XV}$ ao trovar, e não à estrutura da poesia como techné poetike. Isso decorrera do fato de que tal campo de conhecimentos pertencia na Antiguidade preferencialmente à arte musical, como mostram os tratados de Plutarco e Santo Agostinho sobre música. Essa questão foi desenvolvida por mim em outro trabalho (Oliveira, 2005, p.xi-|xxxviii), em que mostro a coexistência, desde a Antiguidade, de duas noções poéticas antagônicas, em que uma se baseia na materialidade sonora das palavras e sua composição eufônica, e outra que se centra principalmente na representação conceitual por meio das palavras. A Poética aristotélica, neste sentido, se organiza segundo uma ideia de poesia contrária àquela baseada na metrificação e no ritmo, excluindo, com isso, a melopeia, isto é, a música, da sua estrutura essencial: embora seja um "ornamento" maior da poesia trágica, para uma poética aristotélica a música permanece sempre ornamento, ou seja, acidente, não substância. Os autores dos séculos XVI e XVII que retomam a Poética não perdem de vista a sentença aristotélica que afirma errarem os antigos ao vincularem a poesia ao metro:

ajuntando à palavra "poeta" o nome de uma só espécie métrica, aconteceu denominarem-se a uns de "poetas elegíacos", a outros de "poetas épicos", designando-os assim, não pela imitação praticada, mas unicamente pelo metro usado (ARISTÓTELES, 1992, 47b 13-14).

0 metro, a cadência da fala, o jogar com as palavras, encantatório no uso de parônimos e homônimos, de rimas e ritmos que "bajulam as orelhas" e ofuscam o encadear das sentenças e suas imagens sob repetições melodiosas da elocução, tudo isso é alheio à definição aristotélica de poesia como imitação, a qual, por tratar de universais, aproxima-se da filosofia. Essa poesia, para a imita- ção racional das ações humanas, é suposto se sustentar sobretudo na clareza e, para a elevação dos afetos, numa linguagem metafórica, que "pinte como num quadro", evidenciando as imagens certas contidas no pensamento, sem necessidade sequer da representação dramática. Para Aristóteles, "a tragédia atinge seu efeito, do mesmo modo como a epopeia, sem recorrer a movimentos, pois basta a leitura para aparecer sua qualidade"; e "além disso, tem a vantagem de ser visivel na leitura e na representação" (ARISTÓTELES, 1996, 62 b 11-13 e 17-18). Quer dizer, mesmo considerando que a leitura das tragédias e epopeias era oral, o texto aristotélico opõe a feitura de imagens por meio da fala àquela que efetivamente se realiza em cena, não tratando das potencialidades sonoras da leitura oral para o deleite ou o ensinamento poéticos.

\section{Poemas melífluos e medíocres}

Não é difícil reconhecer, em grande parte da censura à chamada poesia cultista, tópicos que provêm de uma argumentação aristotélica baseada na clareza e elevação dos conceitos, desgastada já no fim do Seiscentos: que é obscura nos termos e nas construções, que infere conclusões erradas, que se resume a rumor ou estrépito de palavras, que usa de metáforas frias, as quais impossibilitam tanto deleites, como ensinamentos. Figuras prediletas suas, inclusive, são aquelas - de que estão repletos os poemas de Manuel Botelho -, que, ao invés da elevação dos conceitos, sublinham a melodia do verso, por meio de isocolos, antíteses, quiasmos, paronomásias, aliterações. $\mathrm{Na}$ poesia de Botelho de Oliveira, imitador declarado de poetas "cultos", caberiam inteiramente as afirmações de que em seus poemas as significações não se firmam, deslizando de umas coisas para outras por conta de homologias que partem de semelhanças a princípio meramente sonoras, efetuando assim falácias (que são facécias), numa poesia difícil e por vezes obscura, em que a simplicidade e chaneza aparentes do argumento recebem galas de linguagem equívoca. Leia-se, por exemplo, o madrigal XIX de Música do Parnasso, intitulado Conveniências do rosto e peito de Anarda:

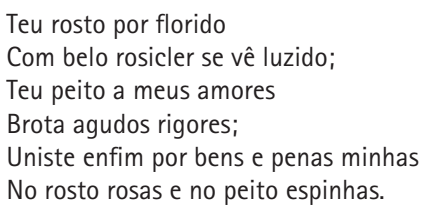

A facécia reside em inverter a metáfora de base, lugarcomum da poesia lírica petrarquista, que afirma ser o rosto da mulher amada uma rosa florescente. Na descriptio cristalizada pela retórica medieval da poesia, em que, após o louvor do rosto feminino, segue-se o das demais partes do corpo, com destaque para os cabelos, o colo, as mãos etc. Tal descrição epidítica visa sempre a realçar a perfeição da mulher, ao destacar a beleza e graça de cada uma das suas partes corpóreas, sendo que o conjunto delas há de manifestar, assim, a unidade de sua beleza interior, por outro nome, virtude. Aqui, porém, com uma comicidade algo duvidosa, o madrigal 
passa à descrição metafórica do tronco (!) da mulher, de modo a acentuar a incongruência entre a beleza do rosto da amada e a dureza dos seus afetos: uma vez que em seus rigores ela demonstra falta de amor e insensibilidade, seu peito pode ser equiparado, por uma conveniência particular, ao caule de uma roseira, que possui agudos espinhos. A carga afetiva da imagem se concentra enfim na transmutação do termo em puro equívoco: espinhos de rosa, num busto feminino vituperado, equivalem a... espinhas. 0 resultado é um retrato bem feio: conveniente à inconveniência da amada detestada na circunstância do poema.

Um outro exemplo em que a composição sonora - nada arbitrária, portanto - realiza-se em conceito é a "décima" de Música do Parnasso justamente intitulada Eco de Anarda:

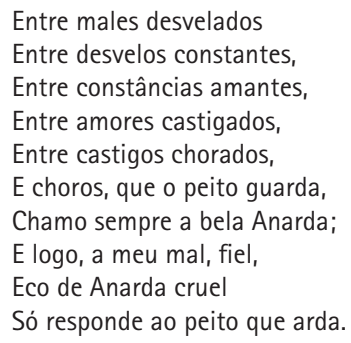

A anáfora dos cinco primeiros versos insiste na angústia do amante, posto entre afetos repisados nas ânsias do amor ausente. Esse efeito de angustura é amplificado em contínuo pela progressão da anadiplose (desvelados / desvelos; constantes / constâncias; amantes / amores etc.), que atinge o clímax e resolução na confissão aberta do pranto: e choros, que o peito guarda. Tal catarse pela invocação da amada, que era suposto interromper a cadeia de sofrimento, na verdade opõe e reitera a fidelidade e constância do mal, que não abandona o enamorado, à infidelidade cruel da bela desaparecida que, distante e muda, não se digna a responder-lhe; pelo contrário, ao chamado de Anarda, só o eco solitário da voz apaixonada, agora estrangulada e partida, soluçada entre choros, responde ...arda. A densidade afetiva do poema de modo algum é desdenhável na formulação desse poema, que se resolve no entanto por uma inesperada distensão, proveniente da graça que a conclusão suscita, ao ser o sufixo tornado termo autônomo: -arda. Lembro o Gracián de Agudeza y arte de ingenio, em seu Discurso XXXI, De la agudeza nominal.

\footnotetext{
Es como hidra vocal una dicción, pues a más de su propia y directa significación, si la cortan o la trastruecan, de cada sílaba renace una sutileza ingeniosa y de cada acento un concepto.
}

Não vou tornar àquilo que tanto já se apontou: que a maior parte desses procedimentos da poesia seiscentista, tidos como fúteis, estéreis e artificiais por uma crítica aristotélico-platonizante, devem ser lidos no âmbito de um pensamento poético menos essencialista, que privilegia as imitações, as agudezas, os torneios, desvios, efeitos inesperados, dependentes sempre do gênero, como demonstrações do engenho do poeta - artífice que tem por um de seus principais ofícios desvendar os prodígios semeados pela admirável razão divina nos menores e nos maiores acontecimentos do orbe.

É poesia cujo estilo, "florido", mesmo tratando de coisas elevadas para a doutrina, como o são os episódios da vida de Maria, da vida de Cristo e de diversos santos, não deve ser magnífico como o da poesia heróica, mas mediocre, isto é, "fiorito ed ornato", no dizer de TASSO (1959, p.395). Tal mediocridade do estilo lírico há de ser entendida como um rebaixamento do estilo sublime, ao mesmo tempo que uma elevação do estilo humilde, obtidos por meio de uma certa vaghezza ou brandura nos ornamentos dos conceitos e da elocução, e de doçura e suavidade na composição, uma vez que a poesia lírica se destina não a comover fortemente os ânimos, mas a movê-los com leveza, graciosa e melodiosamente (cf. Hansen, 2002; Carvalho, 2007 e Teixeira, 2001).

Nessa poesia, enfim, não se pretende que o ritmo e a melodia se subordinem ao significado das palavras, nem que estas sejam sempre viris e sábias por refletirem uma alma virtuosa da qual estão ausentes queixas, lamentos e lascivias, e que rejeita, consequentemente, tanto harmonias tristes como ritmos insanos; em dizer isso, sintetizo, imensamente, capítulos ( $\mathrm{x}, \mathrm{XI}$ e XII) do Livro III da República, em que Platão discorre sobre a educação musical na pólis, especificamente sobre o canto, a melodia e o ritmo. Em nada menos do que três passagens desses curtos capítulos, o filósofo enfatiza a subordinação às palavras, como conceitos, seja da harmonia, seja do metro. Numa poesia como a de Botelho de Olieira, pelo contrário, em que a elegância e o prazer são alvo primeiro, procuram-se palavras que se adaptem ao metro e à melodia dos verso. A ênfase maior reside, portanto, numa poesia cuja elegância poética (eufonia, ritmo, musicalidade) transporta na doçura do metro ensinamentos assim suavizados. Ou seja, segundo o ciceroniano Partitiones oratoriae (CÍCERO, IX, 31-2) que traga consigo "admirações, expectativas, soluções inesperadas, interpostos movimentos de ânimos, diálogos de pessoas, com dores, iras, medos, alegrias, cobiças", como é próprio da narrativa suave. Se por fineza o século XVII entende "ação que se faz com primor, com galanteria, com cortesania", "ação com que se mostra o grande amor que se tem a alguém", "sutileza", "destreza", "coisa perfeita", "excelência", doçura pressupõe suavidade, agrado aos sentidos surpreendidos, amenidades propícias ao contentamento de leitores e ouvintes, como o demonstram as definições do Vocabulário de Bluteau. Ser o plectro doce e fino, enfim, implica primor de arte e de afetos gentis, capazes de encantar e maravilhar os leitores por meio de deleites adequados a um entendimento surpreendido com o já sabido.

\section{A Ilha de Maré cheia de graça}

Muitos outros poemas em que o "estilo florido" se converte em própria matéria poética poderiam ser citados, mas destaco apenas aquele em que, por evidente, a noção sobressai. De forma excelente, ela se concentra na célebre silva $\dot{A}$ 
ilha de Maré, em que muitos viram nativismo, que muitos refutaram, e cujos versos ambos os lados desprezaram.

A imagem da llha de Maré na "silva" de Botelho de Oliveira tem como fontes, contrafeitas, o "jardim das delícias" da ilha de Chipre, morada de Vênus, no canto VII do Adone de Marino, bem como a "ilha namorada", no canto IX d'Os Lusíadas de Camões. Porém, todos os confrontos entre as delícias da ilha do Recôncavo e aquelas encontradas nas outras partes do mundo dos antigos, cujo paragone resulta sempre na superioridade dos elementos presentes em Maré, estão emoldurados pelo cotejo final entre a deusa do amor pagã e a do amor cristão, com predomínio, evidente, da última, deusa do amor casto e virtuoso, porque verdadeiro, de nome derivado do próprio mar, "Maria":

E se algum tempo Citereia a achara,

Por esta sua Chipre desprezara,

Porém tem com Maria verdadeira

Outra Vênus melhor por padroeira.

Por isso, o poema todo há de ser lido como uma comparação epidítica que não visa senão ao elogio da ilha da Bahia, mostrada como uma maravilha, cuja sobrenaturalidade é fruto da bênção divina e não franqueia os limites do verossímil. Não se trata, portanto, de uma fantasia inverossímil, incongruente, como as dos mitos e feitiçarias, seja da antiguidade pagã, seja da medievalidade. Em suas linhas principais, o poema consiste em uma descriptio da ilha de Maré, o que desde o título e na estrofe final se justifica por ser ela termo da cidade da Bahia, resumo ou apodo do Brasil. Ser uma descriptio, já se sabe, significa desde logo pôr sob luz brilhante e admirável tudo o que, na descrição, possa adornar a coisa descrita de qualidades e virtudes, produzindo o seu louvor. A descriptio é antes de tudo uma figura da evidentia. Assim, a descrição evidencia as belezas da ilha com ostensão, mediante hipotiposes, mostrando-as presencialmente e como que tornando o leitor um espectador delas: como num teatro, estupefacto como em frente a uma pintura, no tempo presente da enunciação. Não há uma narração de coisas passadas, mas tudo se passa como se à vista do leitor, aprisionado na paisagem pela insistência do dêitico aqui, isto é, neste lugar e momento: Aqui se cria o peixe regalado; Não falta aqui marisco saboroso; Os melões [...] aqui são gerados; Aqui não faltam figos; Aqui se fabricaram três capelas; Outra capela aqui se reconhece. Etc.

Para tanto, Botelho de Oliveira segue rigoroso as recomendações das Instituições oratórias de Quintiliano acerca da demonstração epidítica de um locus (no Livro III, cap.7) começando por definir a ilha, o que faz com uma pretensa etimologia motivada: é uma terra rodeada por mar e daí seu nome, "Maré". Essa designação, porém, em nosso culto autor, é fonte de mais de um tropo, pois maré é nome derivado, metaforicamente, do deus do mar que rodeia a ilha, Netuno. 0 envolvimento da ilha pelo mar dá razão a nova metáfora, ao trazer o poeta, já na primeira estrofe, a imagem dum amante que abraça e penetra a amada - já que a lírica, ora, trata justamente de deleites. Afirmando ser reciproco o amor entre a ilha e o mar, seu nome se justifica, amplificadamente, nas diversas expressões com que se significam aspectos desse amor: ilha de maré de rosas (pelas despreocupadas alegrias do amor); ilha de marés vivas (pelas ondas cheias com que o mar a invade); ilha de marés mortas (quando a água do mar, afastando-se da terra, provoca-Ihe saudades). Todas essas figuras caracterizam, numa linguagem afetiva - sensualíssima - a ilha como uma terra receptiva, amorosa e fértil.

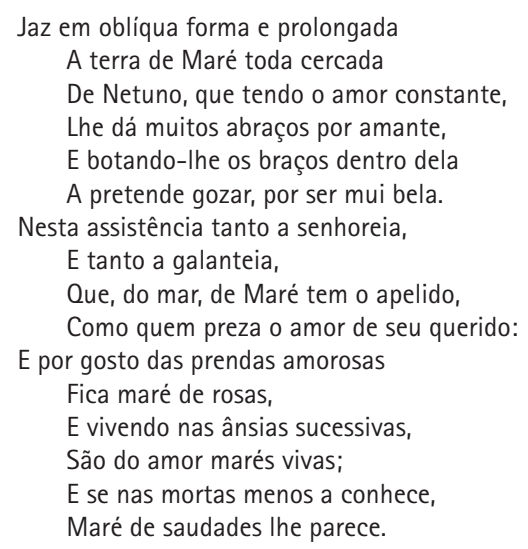

Além disso, a descrição da ilha é feita de modo a conter uma narração, em que a clareza das imagens, novamente, se destina a provocar afetos e deleites, sem se pôr a serviço do docere, isto é, de ensinar a qualquer leitor desavisado o que seja a ilha de Maré. Por essa razão, são descabidas discussões, com base no poema, a respeito da inexistência ou existência de figos e melões e uvas no Recôncavo da Bahia no Seiscentos! Por meio de um belo artifício, o poeta - senhor de (alto) engenho - faz como se a visão da ilha fosse oferecida a partir de um ponto no mar, por alguém dela se aproximando devagar (num barco...), podendo assim ver sucessiva e admiradamente, do mais amplo ao particular, do contorno ao interior, como com uma luneta, sua forma obliqua, espraiada à tona d'água, seus outeiros, as canoas e os saveiros à sua volta, os pescadores dentro deles a lançar redes e anzóis, os peixes e mariscos que apanham, a verdura da terra, as frutas, os legumes no solo, as construções que se distinguem na paisagem: um engenho, três capelas.

Este modo se descrever, centrado nos procedimentos amplificativos como meios de suscitar os afetos, em que 0 acento recai no fingimento de presença dramática, transformando ouvintes e leitores em espectadores ativos, caracteriza uma ecfrase: "técnica de produzir enunciados que têm enargeia, presentando a coisa quase como se o ouvido a visse em detalhe", segundo a definição de Hermógenes discutida por João Adolfo HANSEN (2006, p.85). Por essa descriptio estimar não um ensinamento, mas um encanto, não um realismo, mas uma composição poética maravilhosa, a aparência da ilha se mimetiza em caráter, a reproduzir a Moral do império do qual a ilhota é parte - privilegiada, como foi dito, por ser sua síntese melhor. Se exteriormente parece feia, o é do mesmo modo que a concha, que guarda em si a pérola fermosa; se tem outeiros, é por que neles se mostram as presunções do mundo; 
se, finalmente, na azáfama dos barcos que sulcam a baía, uns vão buscando da Cidade a via e outros dela se vão com alegria, é porque na desigual ordem / consiste a fermosura na desordem. A ilha é um mundo abreviado, mas inteiro, uno na sua semelhança com o Mundo criado, em que se há de desconfiar das aparências, em que até nos peixes com verdade pura / ser pequeno [...] é desventura, e em que, finalmente, em suas diferenças, se compõe a harmonia da natureza, vária e antitética.

Tal variedade, razão da formosura, é o que a descriptio em que consiste o poema focaliza. 0 deambular do olhar, envolvendo e particularizando os elementos admiráveis da ilha, intensifica o caráter digressivo da descrição, propiciando a exposição minuciosa e plural de cada elemento do conjunto, em suas qualidades susceptíveis de causar espanto e maravilhar o leitor - sempre desejoso de ser deleitado. Assim se há de entender o catálogo de peixes e mariscos, em que o sentido (inteligivel, é claro) do paladar é afetado por uma série de adjetivos que lhe correspondem: regalo, regalado, sustância, gosto, gostoso, tempero, temperado, apetite, convite, saboroso, fastio...

E assim também o extenso catálogo de frutas e legumes que ocupa a maior parte do poema, numa gala de termos raros e sonoros, luxuosos como convém à primavera dessa ilha, em que as folhas verdes brilham sem cessar, esmeraldas de abril. Esse catálogo de vegetais da silva (por outro nome, "selva"), é subdividido em três: o das frutas importadas, o das naturais e o das raízes. Entre as frutas do primeiro catálogo, a cana-de-açúcar dulcíssima é a primeira a ser mencionada, como era de se esperar; das demais, cada uma é comparada às da terra de origem, mostrando vantagem, seja pela doçura (as "laranjas da terra" e os figos), seja pelo tamanho (as "laranjas da China"), seja pela quantidade (os limões), pela beleza (as cidras), pelo número das colheitas (as uvas moscatéis), pelo sabor (os melões), pela qualidade (as melancias), pela cor (as romãs).

No segundo catálogo, os principais termos de comparação referem-se ao sabor, o odor, a cor e o tato das frutas "próprias" em relação àquelas que frutificam apenas na Europa: a castanha do caju é melhor que a de França, Itália, Espanha; as pitombas são no gosto melhor do que as cerejas; as bananas competem com maças, ou baonesas, / com peros verdeais ou camoesas; o marcujá como é mole, / qual suave manjar todo se engole; a mangaba tem o cheiro famoso, como se fora almíscar oloroso; enfim, o ananás, que é muito mais que o pêssego excelente [...] por maior, por mais doce, e mais cheiroso. Estabelecendo a comparação com frutos europeus tidos por excelentes, Botelho de Oliveira não só logra trazê-los ao seu poema, multiplicando, por assim dizer, a variedade dos que arrola, como também superlativiza as plantas da terra pelo confronto com as estranhas. 0 cromatismo também é rico, e encarece o espectro de prazeres que podem suscitar as frutas, segundo o sentido (inteligivel, novamente) da visão: cajus belos, vermelhos, amarelos; pitangas rubicun- das; pitombas douradas; maracujá mais do que açúcar rosado; mangaba salpicada de tintas. E o mesmo em relação aos legumes: mangarás brancos ou vermelhos; inhames cândidos, carás roxos etc.

Sob a denominação de "legumes", por fim, Botelho de Oliveira inclui raízes como mangarás, batatas, inhames, carás e aipins, com destaque para a mandioca e sua farinha, bem como o milho e o arroz, os quais todos são do Brasil sustentos duplicados. Aqui, o principal termo que os reúne, mas do que as belezas sensíveis que predominam entre as frutas, é a utilidade para a alimentação: os inhames podem tirar a fome ao mais faminto; das batatas se faz a rica batatada, / das Bélgicas nações solicitada; da farinha de mandioca faz-se o beiju, que grande ventagem leva ao pão de trigo etc. Todo este rol de "frutos da terra", em sua variedade, são partes da dita formosura da ilha, a qual, naturalmente, assim é por serem honestos seus prazeres. A riqueza, suavidade, beleza, paladar, tato, odor, que cada um deles e seu conjunto oferecem aos sentidos, concorrem para o elogio da ilha, qualificando-a como doce e útil; o poema, por sua vez, imitando-Ihe doçuras e utilidades, ofício maior do engenho poético, deleita e instrui o leitor maravilhado, bem aprendido e desviado paradigma horaciano.

Um único sentido, o da audição, pareceria estar ausente nesse fausto de delícias, não soubéssemos que a sonoridade rara - e melodiosa - de tais frutas e legumes naturais da terra até hoje são capazes de estranhar agradavelmente os ouvidos, mesmo, é claro, numa leitura silenciosa: mangava, macujé, mangará, cará, inhame, beiju, aipim...

A natureza da ilha é sintetizada nos ciúmes e invejas que, por esses bens, o Brasil causa a Portugal, e é causa de ter sido acometida por holandeses (Ah se Holanda os gozara!). A sintese se materializa nos quatro elementos em que ela excele, coincidindo seus $A A$ com suas virtudes: Arvoredos sempre verdes, Ares puros, Águas sadias, Açúcar deleitoso.

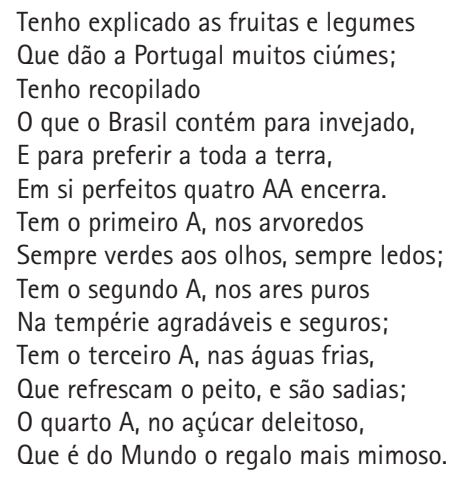

A representação das letras como signos de realidades essenciais é um lugar comum, que recupera sofisticamente noções já vistas da potência sonora como semelhança conceitual. Isso ocorre até nos primeiros cronistas do Brasil, que repetem com insistência a máxima de que as diversas línguas dos índios do Brasil não têm, nenhuma 
delas, nem $F$, nem $L$, nem $R$ - evidência de nenhum deles poderem ter Fé, Lei, ou Rei. Aqui, o poeta usa o mesmo procedimento de tomar a letra A como signo dos conceitos elegidos, porém não para vituperar, e sim para fazer uma súmula do elogio à ilha, que em si perfeitos quatro $A A$ encerra. A letra $A$ é primeira em todos os alfabetos, dizem, a primeira de todos os homens, também expiração de Deus - que se diz Alfa e Ômega. Certamente, as árvores, os ares e as águas insignes demonstram por si dádivas divinas à ilha, que a tornam maravilhosa em seus elementos naturais; mas a perfeição última é dada pelo açúcar, produto do labor e do artifício humano, cuja fartura, riqueza e doçura excepcionais são permitidas pela divindade para completude da glória da ilha e seu louvor. Por essa razão, o engenho famoso que aí existia, destruido pelos batavos hereges que a cobiçavam e a todo o Brasil, renasceu em seguida, Fênix católica. Tornada templo divino toda a ilha, portanto, o reconhecimento visível da fé é dado pelos homens que nela não descuidaram de construir três capelas, ditosamente belas, dedicada uma a Nossa Senhora das Neves, outra a São Francisco Xavier e a terceira a Nossa Senhora da Conceição.

Deste modo, todos os deleites exuberantes da ilha de Maré se mostram coniventes com a virtude católica, ibérica. Vênus, Apolo e suas Musas são alegorias, ao passo que Maria é padroeira da poesia e do amor verdadeiros. As cores, sabores e odores raros, imitados numa locução distinta e harmoniosa, que procura se assemelhar às coisas extraordinárias e felizes que descreve, são mostras dos benefícios divinos derramados sobre a cidade do Salvador, a qual reverencia a Fé, obedece à Lei, se submete a seu Rei. Se delectare admiravelmente é o efeito último almejado em poemas encomiásticos como esse, tal deleite se reveste, por sua vez, de uma eficácia precisa, em termos de adequação e conjunção ao Império e à Igreja.

\section{Referências}

ARISTÓTELES. Poética. Trad., pref. introd., coment. e apêndices de Eudoro de Sousa. Lisboa: IN-CM, 1992. 3.ed.

BLUTEAU, Raphael. Vocabulario portuguez, e latino, aulico, anatomico, architectonico, bellico, botanico ... Hildesheim; New York : Georg Olms Verlag, 2002. 10 v. Facsimile: Coimbra : No Collegio das Artes da Companhia de Jesu, 1712[1728].

CARVALHO, Maria do Socorro F. de. A poesia de agudeza em Portugal. Estudo retórico da poesia lírica e satírica escrita em Portugal no século XVII. São Paulo: Humanitas; Edusp; Fapesp, 2007.

CHASIN, Ibaney. 0 canto dos afetos. São Paulo: Perspectiva, 2004.

DIONYSIUS DE HALICARNASSUS. On Literary Composition in Critical essays. Harvard University Press, 1985, vol.ı, Col. Loeb Classical Library.

DIONÍSIO de Halicarnaso. On Literary Composition in Critical essays, vol.ii. Harvard University Press, 1985, col. Loeb Classical Library.

GRACIÁN, Baltazar. Agudeza y arte de ingenio. Madrid: Espasa-Calpe, 1974.

HANSEN, João Adolfo. Introdução, in A. Pécora (org.), Poesia Seiscentista. São Paulo, Hedra, 2002.

.Categorias epidíticas da ekphrasis. Revista USP n.71, set./nov.2006. São Paulo.

HORÁCIO, Ars Poetica in Dante Tringali. A arte poética de Horácio. São Paulo: Musa, 1993.

LÓPEZ, Pinciano, Afonso. Philosophia Antigua Poética. Madrid: Thomas lunti, 1596.

MARINO, Giambattista. Adone. A cura de Giovanni Pozzi. Milano: Adelphi, 1988.

OLIVEIRA, Manuel Botelho de. Poesia completa. Música do Parnasso. Lira sacra. Introd., org. e fixação do texto de Adma Muhana. São Paulo: Martins Fontes, 2005.

SCHWARTZ, Stuart. Segredos internos. Engenhos e escravos na sociedade colonial. São Paulo: Companhia das Letras, 1999.

TASSO, Torquato. Discorsi dell'Arte Poetica, in Prose. Milão; Nápoles: Ricardo Ricciardi, 1959.

TEIXEIRA, Ivan. 0 engenhoso fidalgo Manuel Botelho de Oliveira. Revista USP, n.50. São Paulo, 2001.

VIEIRA, Antônio. Cartas, coord. e anot. por J. Lúcio de Azevedo. Lisboa: in-cm, 1997, 2 ed., 3 tomos.

Adma Muhana é doutora em Filosofia pela Universidade de São Paulo. Tem se especializado em trabalhos acerca do século XVII, sendo convidada a proferir conferências em instituições acadêmicas de diversos países, relativas a seus estudos críticos e à edição de fontes daquele período. Entre eles, destacam-se a edição de manuscritos do pe. Antônio Vieira, depositados na Torre do Tombo em Lisboa, em Apologia das coisas profetizadas (1994) e a publicação de fundos inquisitoriais em Os autos do processo de Vieira na Inquisição (1995, reed. 2008); sua tese de doutorado, A epopeia em prosa seiscentista (1996); o manuscrito inédito do tratadista português Manuel Pires de Almeida, Poesia e pintura, ou pintura e poesia (2002); a Poesia completa de Manuel Botelho de Oliveira (2005) e Os Infortúnios trágicos da constante Florinda (2006), de Gaspar Pires de Rebelo, também do Seiscentos português, além de diversos artigos e capítulos de livros, no Brasil e no exterior. 